\title{
Environmentally benign peptide synthesis using liquid-assisted ball- milling: application to the synthesis of Leu-enkephalin
}

\author{
Julien Bonnamour, Thomas-Xavier Métro,* Jean Martinez and Frédéric Lamaty*
}

5

This paper describes an original methodology for peptide bond synthesis avoiding toxic solvents and reactants. Ballmilling stoichiometric amounts of Boc-protected $\alpha$-amino acid $N$-carboxyanhydrides (Boc-AA-NCA) or Boc-protected $\alpha$ 10 amino acid $N$-hydroxysuccinimide esters (Boc-AA-OSu) with $\alpha$-amino acid alkyl ester salts in the presence of $\mathrm{NaHCO}_{3}$ and a minimal quantity of EtOAc led to the production of di- to penta-peptides in an efficient and environmentally benign manner. This approach was successfully applied to the 15 synthesis of Leu-enkephalin.

Synthetic therapeutic peptides have recently regained interest as promising drug candidates, due to the rise of alternative routes of administration and development of new strategies to improve both their in vivo stability and bioavailability. ${ }^{1}$ Besides this high 20 potential, peptide production techniques suffer from the huge amount of solvent required during the synthesis and purification steps. In order to allow suitable solubilisation of the reactants as well as high reaction speed, solvents such as DMF, DMAc, NMP or DCM are commonly used. ${ }^{2,3}$ Unfortunately, these solvents 25 present either high boiling point or high toxicity. In addition, peptide synthesis often requires the use of soluble organic bases such as triethylamine, $N, N$-diisopropylethylamine or piperidine for deprotonation of ammonium salts or for removal of the Fmoc protecting group. While being chemically efficient, these bases 30 are flammable, corrosive and toxic. Thus, finding a convenient, efficient and environmentally friendly procedure is of high interest. $^{4}$

While being focused on the complete elimination of problematic organic solvents, ${ }^{5}$ our group recently published a 35 solvent-free procedure for the synthesis of di- and tri-peptides starting from Boc-protected $\alpha$-amino acid $N$-carboxyanhydrides (Boc-AA-NCA), $\alpha$-amino acid alkyl ester hydrochlorides $(\mathrm{HCl} \cdot \mathrm{H}-\mathrm{AA}-\mathrm{OR})$ and $\mathrm{NaHCO}_{3} .{ }^{6}$ In this strategy, the reactants were chosen for their low toxicity and homogenisation of the 40 reaction mixture was established via ball-milling. ${ }^{7}$ This approach allowed the production of di- and tri-peptides in high yields, but with relatively low milling loads (ML). ${ }^{8,9}$ In a typical experiment, Boc-Phe-NCA, $\mathrm{HCl} \cdot \mathrm{H}-\mathrm{Leu}-\mathrm{OMe}$ and $\mathrm{NaHCO}_{3}$ were placed in a $10 \mathrm{~mL}$ stainless steel jar with one $10 \mathrm{~mm}$ diameter ball, 45 accounting for a milling load of $5.9 \mathrm{mg} / \mathrm{mL}$, and after $20 \mathrm{~min}$ of vigorous agitation, $28 \mathrm{mg}$ of the dipeptide Boc-Phe-Leu-OMe could be isolated.

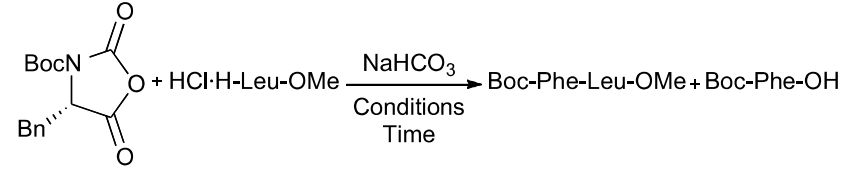

Boc-Phe-NCA
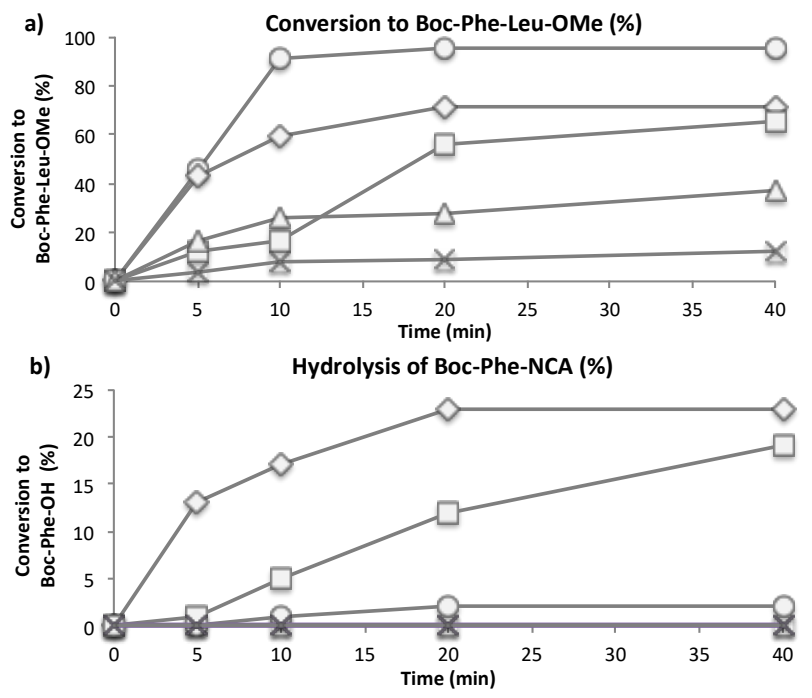

-O-Ball-milling, $\mathrm{ML}=22.5 \mathrm{mg} / \mathrm{mL}$, EtOAc $(\eta=1.4 \mu \mathrm{L} / \mathrm{mg}$ )

$\checkmark$ Ball-milling, $\mathrm{ML}=5.9 \mathrm{mg} / \mathrm{mL}$, solvent-free $(\eta=0 \mu \mathrm{L} / \mathrm{mg}$ )

$-\square$-Ball-milling, $\mathrm{ML}=22.5 \mathrm{mg} / \mathrm{mL}$, solvent-free $(\eta=0 \mu \mathrm{L} / \mathrm{mg})$

$\triangle-$ Round-bottom flask with classical stirring, DMF $(\eta=1.4 \mu \mathrm{L} / \mathrm{mg}$ )

$*$ Round-bottom flask with classical stirring, EtOAc $(\eta=1.4 \mu \mathrm{L} / \mathrm{mg})$

Fig. 1 Effects of agitation conditions on the reaction of Boc-Phe-NCA with $\mathrm{HCl} \cdot \mathrm{H}-\mathrm{Leu}-\mathrm{OMe}$. Conversion into Boc-Phe-Leu-OMe and Boc-Phe-

${ }_{50} \mathrm{OH}$ was determined by HPLC by quenching the reaction medium with $\mathrm{BuNH}_{2}$. ML stands for milling load $(\mathrm{mg} / \mathrm{mL})$ and $\eta$ for the ratio of added liquid volume to the mass of solid reactants $(\mu \mathrm{L} / \mathrm{mg})$.

In our quest to synthesise longer peptides in an environmentally benign fashion, we needed to set up conditions 55 allowing the scale-up of small peptide production. The more straigthforward way was to raise the milling load in the ball-mill reactor, that is to perform the reaction with more material in an identical reactor volume. Unfortunately, raising the milling load resulted in a sharp decrease in the speed of dipeptide formation. 60 Indeed, while $43 \%$ conversion into the dipeptide Boc-Phe-LeuOMe was obtained after 5 min agitation with a milling load of 5.9 $\mathrm{mg} / \mathrm{mL}$, only $12 \%$ conversion was reached after the same amount of time with a milling load of $22.5 \mathrm{mg} / \mathrm{mL}$ (Fig. 1a). This disappointing result could be explained by the highly viscous and ${ }_{65}$ sticky reaction media that would led to mass transfer limitations when excessive material was in the reactor, thereby dramatically hampering the global speed of dipeptide formation. This hypothetical mass transfer limitation may also account for the formation of Boc-Phe-OH resulting from Boc-Phe-NCA 70 hydrolysis $(23 \%$ conversion into Boc-Phe-OH after 20 min 
reaction; Fig. 1b). At this point of the study, the sharp decrease in the speed of formation of Boc-Phe-Leu-OMe while raising up the milling load, along with the partial hydrolysis of Boc-Phe-NCA, did not support the use of this approach in the synthesis of longer 5 peptides.

To overcome these limitations, we envisioned the use of a liquid grinding assistant that could promote the mass transfer of the reactants within the reactor. ${ }^{10}$ Following our general approach based on the twelve principles of green chemistry, ${ }^{11}$ we selected 10 ethyl acetate due to its low toxicity (EtOAc has been approved by the U. S. Food \& Drug Administration as a food additive). ${ }^{12,13}$ While $17 \%$ conversion into the dipeptide was obtained after 10 min in solvent-free conditions with a milling load of $22.5 \mathrm{mg} / \mathrm{mL}$, performing the same reaction in the presence of a small amount 15 of EtOAc $(1.4 \mu \mathrm{L} \text { EtOAc per mg of reactants; } \eta=1.4 \mu \mathrm{L} / \mathrm{mg})^{14}$ led to $91 \%$ conversion into the dipeptide after the same amount of time (Fig. 1a). Interestingly, the use of EtOAc as a grinding assistant also led to a strong minimisation of Boc-Phe-NCA hydrolysis, as less than $2 \%$ conversion to Boc-Phe-OH was 20 observed after 20 min reaction (Fig. 1b). Besides, using EtOAc as a grinding auxiliary changed the visual aspect of the reaction medium from a highly sticky paste to a white cream-like texture. We assumed this was related to a better mixing of the reactants in the jar, resulting in a higher speed of dipeptide formation and a 25 reduction of Boc-Phe-NCA hydrolysis. To control that EtOAc itself was not the only responsible for increasing the speed of dipeptide formation, the reaction was performed with an identical $\eta$ ratio in a round-bottom flask equipped with a magnetic stirrer and placed under vigorous agitation over a magnetic stirring 30 plate. In this case, less than $10 \%$ conversion was obtained after 20 min (Fig. 1a), indicating it was the combination of ball-millinduced vigorous agitation and use of EtOAc as the grinding assistant that was necessary to produce the dipeptide efficiently.
Since the majority of the published peptide syntheses are 35 performed in DMF, another assay using this solvent was realised under classical magnetic stirring with identical $\eta$ ratio. After mixing the reaction medium for $20 \mathrm{~min}, 28 \%$ conversion into Boc-Phe-Leu-OMe was obtained (Fig. 1a), indicating that combination of DMF with classical mixing was less efficient than 40 utilising EtOAc under ball-milling agitation.

Table 1 Influence of $\eta$ ratio and number and size of balls on the yield

\begin{tabular}{cccc} 
Entry & $\eta(\mu \mathrm{L} / \mathrm{mg})^{a}$ & Number of balls & Yield $(\%)^{b}$ \\
\hline 1 & 1.4 & $1(10 \mathrm{~mm})$ & $95^{c}$ \\
2 & 0.7 & $1(10 \mathrm{~mm})$ & 76 \\
3 & 1.4 & $2(10 \mathrm{~mm})$ & 85 \\
4 & 1.4 & $3(5 \mathrm{~mm})$ & 93
\end{tabular}

${ }^{a} \eta=$ ratio of added liquid volume to the mass of solid reactants $(\mu \mathrm{L} / \mathrm{mg})$. ${ }^{b}$ Isolated yield. Realised on a $0.38 \mathrm{mmol}$ scale. $\mathrm{ML}=22.5 \mathrm{mg} / \mathrm{mL}$. ${ }^{c}>98 \%$ diastereomeric excess determined by chiral HPLC.

45 After having determined the optimal combination of agitation mode and grinding auxiliary for rapid formation of Boc-Phe-Leu$\mathrm{OMe}$, the latter could be isolated after $20 \mathrm{~min}$ of ball-milling with $95 \%$ yield (Table 1, entry 1). It is worth noting that no racemisation could be observed as the diastereomeric excess of ${ }_{50}$ Boc-Phe-Leu-OMe was found to be superior to $98 \%$ (Table 1, entry 1). Trying to reduce the solvent proportion to a $\eta$ ratio of $0.7 \mu \mathrm{L} / \mathrm{mg}$ resulted in a lower yield of $76 \%$ (Table 1 , entry 2 ). Besides, performing the reaction with two $10 \mathrm{~mm}$ or three $5 \mathrm{~mm}$ diameter balls did not improve the process. In these conditions, ${ }_{55}$ Boc-Phe-Leu-OMe was isolated in $85 \%$ and $93 \%$ yield respectively (Table 1, entries 3 and 4).

Table 2 Synthesis of dipeptides applying liquid-assisted ball-milling strategy

\begin{tabular}{|c|c|c|c|c|}
\hline & 0 & $\underbrace{O}_{\substack{\bar{R}^{2} \\
\text { H }}}$ & $\begin{array}{l}\mathrm{NaHCO}_{3} \text {, EtOAc } \\
\text { Ball-mill, } 20 \mathrm{~min}\end{array}$ & \\
\hline Entry & Boc-AA-NCA or Boc-AA-OSu & $\mathrm{AH} \cdot \mathrm{H}-\mathrm{AA}-\mathrm{OR}^{3}$ & Dipeptides & Yield $[\%]^{a}$ \\
\hline 1 & Boc-Leu-NCA & $p$-TsOH·H-Leu-OBn & Boc-Leu-Leu-OBn & 93 \\
\hline 2 & Boc-Val-NCA & $\mathrm{HCl} \cdot \mathrm{H}-\mathrm{Phe}-\mathrm{OMe}$ & Boc-Val-Phe-OMe & 84 \\
\hline 3 & Boc-Leu-NCA & $\mathrm{HCl} \cdot \mathrm{H}-\mathrm{Pro}-\mathrm{OBn}$ & Boc-Leu-Pro-OBn & 90 \\
\hline 4 & Boc-Ile-NCA & $\mathrm{HCl} \cdot \mathrm{H}-\mathrm{Ile}-\mathrm{OMe}$ & Boc-Ile-Ile-OMe & 95 \\
\hline 5 & Boc-Gly-OSu & $\mathrm{HCl} \cdot \mathrm{H}-\mathrm{Phe}-\mathrm{OMe}$ & Boc-Gly-Phe-OMe & 96 \\
\hline 6 & Boc-Gly-OSu & $\mathrm{HCl} \cdot \mathrm{H}-\mathrm{Pro}-\mathrm{OBn}$ & Boc-Gly-Pro-OBn & 97 \\
\hline 7 & Boc-Tyr(Bn)-OSu & $\mathrm{HCl} \cdot \mathrm{H}-\mathrm{Leu}-\mathrm{OMe}$ & Boc-Tyr(Bn)-Leu-OMe & $98^{b}$ \\
\hline 8 & Boc-Phe-OSu & $\mathrm{HCl} \cdot \mathrm{H}-\mathrm{Phe}-\mathrm{OMe}$ & Boc-Phe-Phe-OMe & 92 \\
\hline 9 & Boc-Phe-OSu & $\mathrm{HCl} \cdot \mathrm{H}-\mathrm{Leu}-\mathrm{OMe}$ & Boc-Phe-Leu-OMe & $83^{c}$ \\
\hline 10 & Boc-Phe-OSu & $p$-TsOH·H-Leu-OBn & Boc-Phe-Leu-OBn & $90^{d} 80^{e}$ \\
\hline
\end{tabular}

${ }^{a}$ Isolated yield. $22.0<\mathrm{ML}<28.4 \mathrm{mg} / \mathrm{mL}$ and $1.1<\eta<1.4 \mu \mathrm{L} / \mathrm{mg}$ unless otherwise noted. ${ }^{b}$ Completed in $1 \mathrm{~h} .{ }^{c}>98 \%$ diastereomeric excess determined by chiral HPLC. ${ }^{d} \mathrm{ML}=28.4 \mathrm{mg} / \mathrm{mL} . \eta=1.1 \mu \mathrm{L} / \mathrm{mg} .{ }^{e} \mathrm{ML}=188.8 \mathrm{mg} / \mathrm{mL} . \eta=$ of $1.1 \mu \mathrm{L} / \mathrm{mg}$. Completed in $2 \mathrm{~h}$.

60

The optimised conditions were then applied to the synthesis of a wide range of dipeptides that were obtained with good to excellent yields (Table 2, entries 1-10). $\alpha$-Amino benzyl ester
${ }_{65}$ para-tosylate salts could be used as the nucleophilic counterpart instead of $\alpha$-amino methyl ester hydrochlorides as Boc-Leu-Leu$\mathrm{OBn}$ was isolated in $93 \%$ yield starting from $p$-TsOH$\cdot \mathrm{H}-\mathrm{Leu}-$ OBn (Table 2, entry 1). Besides, Boc-Val-Phe-OMe and BocLeu-Pro-OBn were synthesised in $84 \%$ and $90 \%$ yield 
respectively (Table 2, entries 2 and 3), showing this approach allowed the use of bulky electrophiles and nucleophiles such as Boc-Val-NCA and $\mathrm{HCl} \cdot \mathrm{H}-\mathrm{Pro}-\mathrm{OBn}$. We then envisioned to broaden the scope of this methodology by replacing the Boc-AA${ }_{5} \mathrm{NCA}$ derivatives by the commercially available Boc-protected $\alpha$ amino acid $N$-hydroxysuccinimide esters (Boc-AA-OSu). ${ }^{15}$ Due to its high water solubility, the low toxic by-product $\mathrm{N}$ hydroxysuccinimide (HOSu) could be easily separated from the reaction media by simple aqueous extraction. Good to excellent 10 yields were obtained when Boc-protected $\alpha$-amino acid $N$ hydroxysuccinimide esters were used as starting material (Table 2, entries 5-10). While Boc-Gly-NCA was not a suitable substrate for the synthesis of dipeptides in previously described conditions, ${ }^{6}$ Boc-Gly-OSu furnished Boc-Gly-Phe-OMe and Boc-

${ }_{15}$ Gly-Pro-OBn with $96 \%$ and $97 \%$ yield respectively when treated with $\mathrm{HCl} \cdot \mathrm{H}-\mathrm{Phe}-\mathrm{OMe}$ and with the structurally constrained $\mathrm{HCl} \cdot \mathrm{H}-\mathrm{Pro}-\mathrm{OBn}$ (Table 2, entries 5 and 6). Similarly, Boc$\operatorname{Tyr}(\mathrm{Bn})-\mathrm{OSu}$ furnished Boc-Tyr(Bn)-Leu-OMe with $98 \%$ yield but required an hour of reaction (Table 2, entry 7). Likewise Boc${ }_{20}$ Phe-NCA, no racemisation could be observed when utilising
Boc-Phe-OSu, as the diastereomeric excess of Boc-Phe-Leu-OMe was found to be superior to $98 \%$ (Table 2, entry 9). When treating Boc-Phe-OSu with stoichiometric amounts of $p$-TsOH·H-Leu$\mathrm{OBn}$ and $\mathrm{NaHCO}_{3}$ in the presence of EtOAc, accounting for a $\eta$ ${ }_{25}$ ratio of $1.1 \mu \mathrm{L} / \mathrm{mg}$ and a milling load of $28.4 \mathrm{mg} / \mathrm{mL}$, Boc-PheLeu-OBn was isolated with $90 \%$ yield (Table 2, entry 10 ). Interestingly, keeping an identical $\eta$ ratio of $1.1 \mu \mathrm{L} / \mathrm{mg}$ while raising the milling load up to $188.8 \mathrm{mg} / \mathrm{mL}$ did not dramatically hampered the reaction as Boc-Phe-Leu-OBn could be isolated in $3080 \%$ yield after $2 \mathrm{~h}$ of ball-milling (Table 2, entry 10). By proceeding this way, $796 \mathrm{mg}$ of the dipeptide could be produced using a simple vibrational ball-mill equipped with a small $10 \mathrm{~mL}$ jar perfectly adapted to a classical laboratory fume hood. This result clearly opened the path to the synthesis of longer peptides 35 using only the non-hazardous reactants ${ }^{16}$ that are Boc-protected $\alpha$-amino acid $N$-hydroxysuccinimide esters (Boc-AA-OSu), $\alpha$ amino acid alkyl ester salts and $\mathrm{NaHCO}_{3}$, combined with minimal amounts of EtOAc or $t$ BuOAc which are considered as preferred solvents according to the sustainable chemistry standards. ${ }^{12}$

40 Table 3 Synthesis of tri-, tetra- and penta-peptides applying liquid-assisted ball-milling strategy

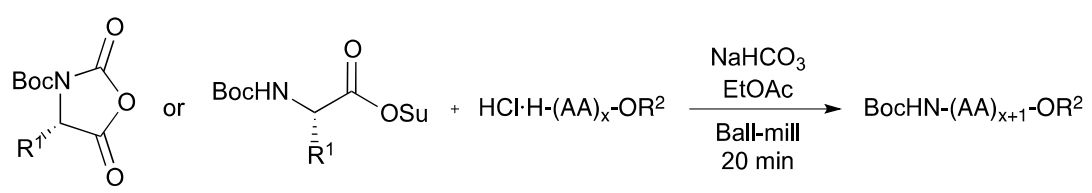

\begin{tabular}{|c|c|c|c|c|}
\hline Entry & Boc-AA-NCA or Boc-AA-OSu & $\mathrm{HCl} \cdot \mathrm{H}-(\mathrm{AA})_{\mathrm{x}}-\mathrm{OR}^{2}$ & Product & ${\text { Yield }[\%]^{a}}$ \\
\hline 1 & Boc-Leu-NCA & $\mathrm{HCl} \cdot \mathrm{H}-\mathrm{Leu}-\mathrm{Leu}-\mathrm{OBn}$ & Boc-Leu-Leu-Leu-OBn & 79 \\
\hline 2 & Boc-Phe-OSu & $\mathrm{HCl} \cdot \mathrm{H}-\mathrm{Phe}-\mathrm{Phe}-\mathrm{OMe}$ & Boc-Phe-Phe-Phe-OMe & 86 \\
\hline 3 & Boc-Lys(Boc)-OSu & $\mathrm{HCl} \cdot \mathrm{H}-\mathrm{Gly}-\mathrm{Pro}-\mathrm{OBn}$ & Boc-Lys(Boc)-Gly-Pro-OBn & 79 \\
\hline 4 & Boc-Trp-NCA & $\mathrm{HCl} \cdot \mathrm{H}-\mathrm{Val}-\mathrm{Phe}-\mathrm{OMe}$ & Boc-Trp-Val-Phe-OMe & 86 \\
\hline 5 & Boc-Ile-NCA & $\mathrm{HCl} \cdot \mathrm{H}-\mathrm{Leu}-\mathrm{Pro}-\mathrm{OBn}$ & Boc-Ile-Leu-Pro-OBn & 86 \\
\hline 6 & Boc-Ile-NCA & $\mathrm{HCl} \cdot \mathrm{H}-\mathrm{Ile}-\mathrm{Ile}-\mathrm{OMe}$ & Boc-Ile-Ile-Ile-OMe & 86 \\
\hline 7 & Boc-Gly-OSu & $\mathrm{HCl} \cdot \mathrm{H}-\mathrm{Gly}-\mathrm{Phe}-\mathrm{OMe}$ & Boc-Gly-Gly-Phe-OMe & 74 \\
\hline 8 & Boc-Gly-OSu & $\mathrm{HCl} \cdot \mathrm{H}-\mathrm{Phe}-\mathrm{Leu}-\mathrm{OBn}$ & Boc-Gly-Phe-Leu-OBn & $93^{b}(94)^{c}$ \\
\hline 9 & Boc-Leu-NCA & $\mathrm{HCl} \cdot \mathrm{H}-\mathrm{Leu}-\mathrm{Leu}-\mathrm{Leu}-\mathrm{OBn}$ & Boc-Leu-Leu-Leu-Leu-OBn & 96 \\
\hline 10 & Boc-Gly-OSu & $\mathrm{HCl} \cdot \mathrm{H}-\mathrm{Gly}-\mathrm{Phe}-\mathrm{Leu}-\mathrm{OBn}$ & Boc-Gly-Gly-Phe-Leu-OBn & $96^{d}(90)^{e}$ \\
\hline 11 & Boc-Tyr(Bn)-OSu & $\mathrm{HCl} \cdot \mathrm{H}-\mathrm{Gly}-\mathrm{Gly}-\mathrm{Phe}-\mathrm{Leu}-\mathrm{OBn}$ & Boc-Tyr(Bn)-Gly-Gly-Phe-Leu-OBn & $88^{f}$ \\
\hline
\end{tabular}

${ }^{a}$ Isolated yield. $6.6<\mathrm{ML}<8.4 \mathrm{mg} / \mathrm{mL}$ and $1.3<\eta<1.6 \mu \mathrm{L} / \mathrm{mg}$ unless otherwise noted. ${ }^{b} \mathrm{ML}=22.9 \mathrm{mg} / \mathrm{mL} .{ }^{c} \mathrm{ML}=152.7 \mathrm{mg} / \mathrm{mL}$. Completed in $40 \mathrm{~min}$ with $t$ BuOAc as the grinding auxiliary. ${ }^{d} \mathrm{ML}=22.2 \mathrm{mg} / \mathrm{mL}, \eta=1.1 \mu \mathrm{L} / \mathrm{mg}$. ${ }^{e} \mathrm{ML}=60.6 \mathrm{mg} / \mathrm{mL}, \eta=1.1 \mu \mathrm{L} / \mathrm{mg}$. Completed in $40 \mathrm{~min}$ with $t \mathrm{BuOAc}$ as the grinding aid. ${ }^{f}$ Completed in $1 \mathrm{~h}$.

To evaluate the environmental impact of this methodology, the ${ }_{45}$ Ecoscale score of Boc-Tyr(Bn)-Leu-OMe synthesis was calculated and compared to the score of traditional protocols used to synthesise peptides. ${ }^{17}$ When realised starting from Boc$\operatorname{Tyr}(\mathrm{Bn})-\mathrm{OSu}$ using $\mathrm{Et}_{3} \mathrm{~N}$ as the base and DMF as the solvent, the synthesis of Boc-Tyr(Bn)-Leu-OMe obtained an Ecoscale score 50 of 69 , which corresponds to an acceptable synthesis. ${ }^{18,19}$ When using our methodology, that is replacement of $\mathrm{Et}_{3} \mathrm{~N}$ and $\mathrm{DMF}$ with $\mathrm{NaHCO}_{3}$ and EtOAc combined with a ball-mill induced homogenisation of the reaction mixture, the Ecoscale score reached 84 , which corresponds to an excellent synthesis. ${ }^{17}$ As a 55 comparison, the commonly used protocol using Boc-Tyr(Bn)$\mathrm{OH}, \mathrm{EtN}(i \mathrm{Pr})_{2}$, BOP reagent and $\mathrm{HCl} \cdot \mathrm{H}-\mathrm{Leu}-\mathrm{OMe}$ in DMF under classical agitation accounted for an Ecoscale score of 58. ${ }^{20}$

In order to synthesise tripeptides using this methodology, ${ }^{21}$ previously obtained Boc-dipeptides required to be deprotected.
${ }_{60} \mathrm{By}$ blowing gaseous $\mathrm{HCl}$ directly on Boc-dipeptides without using any solvent, ${ }^{6}$ the corresponding dipeptide hydrochloride salts could be obtained in quantitative yields. The latter were then treated with a variety of either Boc-AA-NCA or Boc-AA-OSu to furnish tripeptides in good to excellent yields (Table 3, entries 1$\left.{ }_{65} 8\right)$. The apolar tripeptides Boc-Leu-Leu-Leu-OBn and Boc-PhePhe-Phe-OMe were isolated in $79 \%$ and $86 \%$ yield respectively (Table 3, entries 1 and 2). Besides, Boc-Lys(Boc)-Gly-Pro-OBn and Boc-Trp-Val-Phe-OMe were produced in $79 \%$ and $86 \%$ yield, showing that side chain heteroatom-containing tripeptides 70 could also be synthesised in good yields (Table 3, entries 3 and 4). Utilising bulky electrophiles was not an obstacle for the synthesis of tripeptides as treating $\mathrm{HCl} \cdot \mathrm{H}-\mathrm{Leu}-\mathrm{Pro}-\mathrm{OBn}$ and $\mathrm{HCl} \cdot \mathrm{H}-\mathrm{Ile}-\mathrm{Ile}-\mathrm{OMe}$ with Boc-Ile-NCA furnished both Boc-IleLeu-Pro-OBn and Boc-Ile-Ile-Ile-OMe with $86 \%$ yield (Table 3, 75 entries 5 and 6). Less encumbered Boc-Gly-OSu furnished Boc- 
Gly-Gly-Phe-OMe and Boc-Gly-Phe-Leu-OBn with $74 \%$ and $93 \%$ yield respectively (Table 3 , entries 7 and 8 ). It is worth noting that Boc-Gly-Phe-Leu-OBn was synthesised with a high milling load of $152.7 \mathrm{mg} / \mathrm{mL}$, furnishing $937 \mathrm{mg}$ (94\% yield) of 5 the tripeptide (Table 3, entry 8). After transient $\mathrm{HCl}_{\mathrm{g}}$-mediated deprotection, the two tetrapeptides Boc-Leu-Leu-Leu-Leu-OBn and Boc-Gly-Gly-Phe-Leu-OBn were both isolated with an excellent yield of $96 \%$ (Table 3, entries 9 and 10). Finally, treatment of the tetrapeptide $\mathrm{HCl} \cdot \mathrm{H}-\mathrm{Gly}-\mathrm{Gly}-\mathrm{Phe}-\mathrm{Leu}-\mathrm{OBn}$ with 10 Boc-Tyr(Bn)-OSu furnished the pentapeptide Boc-Tyr(Bn)-GlyGly-Phe-Leu-OBn in $88 \%$ yield (Table 3, entry 11 ). To the best of our knowledge, these are the first syntheses of tetra- and pentapeptides based on the use of small amounts of green solvents with stoichiometric amounts of non-hazardous reactants. ${ }^{12,16}$ Besides, 15 the pentapeptide Boc-Tyr(Bn)-Gly-Gly-Phe-Leu-OBn corresponds to the primary structure of Leu-enkephalin, which is an endogenous ligand binding the opioid receptors and has a salient role in processing sensory information in the brain. ${ }^{22}$ It has been isolated and synthesised for the first time by Hughes and 20 coworkers in $1975 .{ }^{23}$ For our part, we completed the Leuenkephalin total synthesis by hydrogenation of the benzyl moieties under $\mathrm{H}_{2}$ atmosphere followed by gaseous $\mathrm{HCl}-$ mediated deprotection of the Boc group (Scheme 1). Boc-Tyr(Bn)-Gly-Gly-Phe-Leu-OBn

40

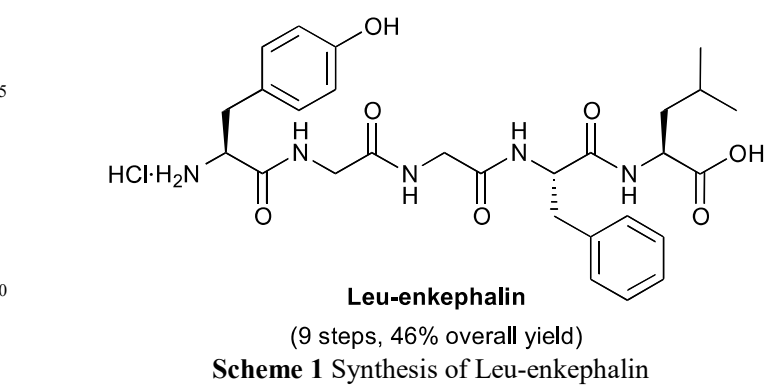

Using this strategy, the synthesis of Leu-enkephalin hydrochloride salt was achieved in nine steps starting from 45 Leucine benzyl ester $p$-tosylate salt, with an overall yield of $46 \%$. Leu-enkephalin synthesis was realised based on:

- Coupling steps using only non-hazardous reactants ${ }^{16}$ and small amounts of EtOAc or $t \mathrm{BuOAc}$, which are considered as preferred solvents according to green chemistry standards. ${ }^{12}$

50 - Solvent-free Boc deprotection steps.

In conclusion, the presented methodology based on liquidassisted ball-milling is a very efficient and environmentally benign route for the synthesis of di-, tri-, tetra- and pentapeptides. Optimisation of the reaction conditions has enabled the ${ }_{55}$ synthesis of a tripeptide and a tetrapeptide close to the gram scale, allowing the synthesis of the pentapeptide Leu-enkephalin in high overall yield.

We thank CNRS, Université Montpellier 2 and Université
Montpellier 1 (post-doctoral grant to J.B.) for financial support 60 and Isochem for providing Boc-AA-NCAs. François Métro is gratefully acknowledged for producing graphical abstract artwork.

\section{Notes and references}

Institut des Biomolécules Max Mousseron (IBMM) UMR 5247 CNRS${ }_{65}$ Universités Montpellier 1 et 2, Bâtiment Chimie (17), Université Montpellier 2, Place Eugène Bataillon, 34095 Montpellier cedex 05,

France. Fax: (+33) 4-6714-4866; Tel: (+33) 4-6714-3847. E-mail:

txmetro@um2.fr; frederic.lamaty@univ-montp2.fr

$\dagger$ Electronic Supplementary Information (ESI) available: General 70 experimental procedures and characterisation data of all compounds. See DOI: $10.1039 / \mathrm{b} 000000 \mathrm{x} /$

1 (a) P. Vlieghe, V. Lisowski, J. Martinez and M. Khrestchatisky, Drug Discov. Today, 2010, 15, 40. (b) F. Albericio and H. G. Kruger, Future Med. Chem., 2012, 4, 1527. (c) L. Pollaro and C. Heinis, Med. Chem. Commun., 2010, 1, 319.

2 D. S. MacMillan, J. Murray, H. F. Sneddon, C. Jamieson and A. J. B. Watson, Green Chem., 2013, 15, 596.

3 DMF stands for $N, N$-dimethylformamide, DMAc for $N, N$ dimethylacetamide, NMP for 1-methyl-2-pyrrolidinone and DCM for dichloromethane.

4 (a) D. J. C. Constable, P. J. Dunn, J. D. Hayler, G. R. Humphrey, J. L. Leazer Jr., R. J. Linderman, K. Lorenz, J. Manley, B. A. Pearlman, A. Wells, A. Zaks and T. Y. Zhang, Green Chem., 2007, 9, 411. (b) V. R. Pattabiraman and J. W. Bode, Nature, 2011, 480, 471. (c) S. Datta, A. Sood and M. Török, Curr. Org. Synth., 2011, 8, 262.

5 (a) T.-X. Métro, J. Bonnamour, T. Reidon, J. Sarpoulet, J. Martinez and F. Lamaty, Chem. Commun., 2012, 48, 11781. (b) P. Nun, V. Pérez, M. Calmès, J. Martinez and F. Lamaty, Chem. Eur. J., 2012, 18, 3773. (c) P. Nun, C. Martin, J. Martinez and F. Lamaty, Tetrahedron, 2011, 67, 8187.

6 V. Declerck, P. Nun, J. Martinez and F. Lamaty, Angew. Chem. Int. Ed., 2009, 48, 9318.

7 For reviews on the utilisation of ball-mills in organic synthesis see: (a) S. L. James, C. J. Adams, C. Bolm, D. Braga, P. Collier, T. Friščić, F. Grepioni, K. D. M. Harris, G. Hyett, W. Jones, A. Krebs, J. Mack, L. Maini, A. G. Orpen, I. P. Parkin, W. C. Shearouse, J. W. Steed and D. C. Waddell, Chem. Soc. Rev., 2012, 41, 413. (b) T. Friščić, Chem. Soc. Rev., 2012, 41, 3493. (c) B. Rodríguez, A. Bruckmann, T. Rantanen and C. Bolm, Adv. Synth. Catal., 2007, 349, 2213. (d) A. Bruckmann, A. Krebs and C. Bolm, Green Chem., 2008, 10, 1131. (e) A. Stolle, T. Szuppa, S. E. S. Leonhardt and B. Ondruschka, Chem. Soc. Rev., 2011, 40, 2317.

8 The milling load (ML) can be defined as the sum of the mass of the reactants per free volume in the jar. The free volume is the volume of the jar minus the volume of the ball. ML is expressed in $\mathrm{mg} / \mathrm{mL}$. See Supporting Information for details on ML calculations.

9 For alternative mechanosyntheses of amides, see ref $5 \mathrm{a}$ and : V. Štrukil, B. Bartolec, T. Portada, I. Đilović, I. Halasz and D. Margetić, Chem. Commun., 2012, 48, 12100.

10 For selected exemples of utilisation of a grinding auxiliary, see: (a) N. Shan, F. Toda and W. Jones, Chem. Commun., 2002, 2372. (b) T. Friščić and W. Jones, Cryst. Growth Des., 2009, 9, 1621. (c) W. Yuan, J. O'Connor and S. L. James, CrystEngComm, 2010, 12, 3515. (d) R. Thorwirth, A. Stolle and B. Ondruschka, Green Chem., 2010, 12, 985; (e) T. Szuppa, A. Stolle, B. Ondruschka and W. Hopfe, Green Chem., 2010, 12, 1288. (f) R. Thorwirth, F. Bernhardt, A. Stolle, B. Ondruschka and J. Asghari, Chem. Eur. J., 2010, 16, 13236. (g) T. Friščić, I. Halasz, P. J. Beldon, A. M. Belenguer, F. Adams, S. A. J. Kimber, V. Honkimäki and R. E. Dinnebier, Nature Chem., 2013, 5, 66.

11 Green Chemistry: Theory and Practice, ed P. T. Anastas and J. C. Warner, Oxford University Press, Oxford, 1998.

12 K. Alfonsi, J. Colberg, P. J. Dunn, T. Fevig, S. Jennings, T. A. Johnson, H. P. Kleine, C. Knight, M. A. Nagy, D. A. Perry and M. Stefaniak, Green Chem., 2008, 10, 31. 
13 U.S. Food and Drug Administration, Code of Federal Regulations Title 21, Chapter I, Subchapter B, Part 173, Subpart C, Sec. 173.228 Ethyl Acetate.

$14 \eta$ is the ratio of added liquid volume to the mass of solid reactants. It is expressed in $\mu \mathrm{L} / \mathrm{mg}$. It has been established for better comparison of mechanochemical with solution-based reactions. For more details, see: T. Friščić, S. L. Childs, S. A. A. Rizvi and W. Jones, CrystEngComm, 2009, 11, 418.

15 For a previous solvent-free methodology using achiral $\mathrm{N}$ hydroxysuccinimide esters as acylating agents of amines, see: F. Ravalico, S. L. James and J. S. Vyle, Green Chem., 2011, 13, 1778.

16 Every Boc-protected $\alpha$-amino acid $N$-hydroxysuccinimide esters and $\alpha$-amino acid alkyl ester salts used in this study (in addition with $\mathrm{NaHCO}_{3}$ ) are considered to be not hazardous substances as defined by the european regulation $\mathrm{N}^{\circ} 1272 / 2008$ or not classified as dangerous according to Directive 67/548/EEC, with the unique exception of proline benzyl ester hydrochloride (skin and eye irritation category 2).

17 K. Van Aken, L. Strekowski and L. Patiny, Beilstein J. Org. Chem., 2006, 2, No. 3.

18 A. Berthelot, S. Piguel, G. Le Dour and J. Vidal, J. Org. Chem., 2003, 68, 9835.

19 See Supporting Information for details on the EcoScale calculations.

20 M. A. Sturgess and F. Kotch, US Pat., US20100087466A1, 2010.

21 For previous exemples of multi-step mechanochemical reactions, see: (a) V. Štrukil, D. Margetić, M. D. Igrc, M. Eckert-Maksić and T. Friščić, Chem. Commun., 2012, 48, 9705. (b) B. Içli, N. Christinat, J. Tönnemann, C. Schüttler, R. Scopelliti and K. Severin, J. Am. Chem. Soc., 2009, 131, 3154. (c) V. P. Balema, J. W. Wiench, M. Pruski and V. K. Pecharsky, J. Am. Chem. Soc., 2002, 124, 6244.

22 (a) W. J. Lukiw, Cell. Mol. Neurobiol., 2006, 26, 1003. (b) J. D. Bower, K. P. Guest and B. A. Morgan, J. Chem. Soc., Perkin Trans. 1, 1976, 2488.

23 J. Hughes, T. W. Smith, H. W. Kosterlitz, L. A. Fothergill, B. A. Morgan and H. R. Morris, Nature, 1975, 258, 577. 